\title{
The impact of COVID-19 on the hotel supply chain management
}

\author{
Vesna Milovanović ${ }^{*}$, Mihailo Paunović ${ }^{2}$, Stefan Avramovski ${ }^{1}$ \\ ${ }^{1}$ University of Kragujevac, Faculty of Hotel Management and Tourism in Vrnjačka Banja, \\ Serbia \\ ${ }^{2}$ Institute of Economic Sciences, Belgrade, Serbia
}

\begin{abstract}
The COVID-19 virus pandemic appeared to be a low-probability, high-impact event that has caused significant disruptions in supply chains world wide. The hotel industry has been one of the most severely affected, with all participants in the supply chain suffering from the crisis. This paper aims to analyze if, and to what extent, hotels in the Republic of Serbia have faced difficulties in supply chain management (SCM) due to the COVID-19 virus pandemic, with special reference to the difficulties in introducing information and communications technologies (ICTs) for SCM. Empirical res earch was conducted in May, 2021 involving managers from 40 hotel companies categorised as 4- and 5-star. The study results reveal that majority of hotel companies have experienced difficulties in SCM and implementation of ICTs for SCM due to the pandemic, while the intensity of difficulties is not found to be correlated with hotel size, category and affiliation.
\end{abstract}

Keywords: COVID-19, supply chain management (SCM), information and communications technologies (ICTs), hotel

JEL classification: M11, M15, I15

\section{Uticaj COVID-19 na menadžment lancima snabdevanja hotelskih preduzeća}

Sažetak: Pandemija izazvana virusom COVID-19 je događaj male verovatnoće i značajnih efekata, koji je prouzrokovao velike poremećaje u lancima snabdevanja širom sveta. Hotelska delatnost je jedna od najteže pogođenih, pri čemu s viučesniciu lancu snabdevanja podnose teret krize. Ovaj rad ima za cilj da is pita da li su se, i u kojoj meri, hoteli u Republici Srbiji suočili sa teškoćama u menadžmentu lancem snabdevanja usled pandemije virusa COVID-19, sa posebnim os vrtom na teškoće pri uvođenju informaciono-komunikacionih tehnologija (IKT) koje se koriste u menadžmentu lancem snabdevanja. Empirijsko is traživanje je sprovedeno u maju 2021. godine, u kojem su učestvovali menadžeri iz 40 hotels kih preduzeća kategorisanih sa 4 i 5 zvezdica. Rezultati is traživanja pokazuju da se većina hotela us led pandemije suočila sa teškoćama u menadžmentu lancem snabdevanja i

*vesna.milovanovic@kg.ac.rs

This article is an open access article distributed under the terms and conditions of the Creative Commons Attribution (CC BY) license (http://creativecommons.org/licenses/by/4.0/). 
uvođenju IKT za menadžment lancemsnabdevanja, s tim da nije ustanovljeno da intenzitet teškoća zavisi od kategorije, veličine i afilijacije hotela.

Ključne reči: COVID-19, menadžment lancima snabdevanja, informaciono-komunikacione tehnologije (IKT), hotel

JEL klasifikacija: M11, M15, I15

\section{Introduction}

Supply Chain Management (SCM) refers to the integration and synchronization of interrelated business processes (Min, 2015). Its role is to enable efficient flow of information, goods and services through the supply chain in order to increase the speed, flexibility, availability and quality of goods, and to cut costs at the same time. This way of functioning helps all participants in the supply chain to gain competitive advantage, while the end-user benefits fromtimely supply of quality goods at a reasonable price. Nowadays, companies can hardly gain competitive advantage on their own, but rather as a part of an efficient and well-managed supply chain. In order to achieve high efficiency of the supply chain, companies can implement numerous information and communications technologies (ICTs) that enable real-time information flow, tracking goods, timely and secure delivery, low stocks, and consequently, the implementation of concepts Just-in-Time (JIT) and lean business.

The COVID-19 virus pandemic has become a global issue affecting people, companies, states, as well as international relations. The way of organizing has changed in all spheres, including education, healthcare, economy, travel, touris m, etc. ICTs have rec eived a huge significance as they have been employed for distance learning and working in order to prevent further spread of the infection. Tourism and hospitality are the most severely affected industries by the pandemic, and not only hotels, restaurants and tourism agencies were affected, but the whole touris m supply chain, including producers of food and other commodities, suppliers, intermediaries, service providers, and touris ts.

This work aims to highlight the impact of the COVID-19 pandemic on the hotels' SCM in the Republic of Serbia, with an emphas is on theimplementation of ICTs for SCM. The paper is structured as follows. After reviewing relevant literature in the field of SCM, COVID-19related business effects, and ICTs for SCM, the hypotheses are developed. Further, the research methodology is presented, followed by the results and discussion. The last part of the paper is devoted to conclusions.

\section{Background}

\subsection{The concept of SCM}

Contemporary market conditions, characterised by intensive competition in almost every field, have made companies more oriented towards efficiency and quality in order to survive in the marketplace and achieve competitive advantage. This has led to specialis ation and, consequently, to the increasing number of separate businesses which are mutually connected into networks to deliver the product or service to the end-users. A supply chain refers to a systemof interrelated business proces ses which extends from the original producer to the end-user. It involves downstream flow of goods, and upstream flow of information. Ayers (2006) defines a supply chain as "life cycle processes comprising physical, information, financial, and knowledge flows whose purpose is to satisfy end-user requirements with products and services frommultiple linked suppliers" (p.4). The process approach has led to 
interfunctional coordination within a company, resulting in higher flexibility, efficiency, and quality. SCM represents an extension of interfunctional coordination, which includes interorg anis ational integration and coordination across the supply chain in order to capture the synergy and allow better decision-making (Min, 2015). Grant et al. (2017) define SCM as "an integrating function with a primary responsibility for linking major business functions and business processes within and across companies into a cohesive and high-performing business model" (p.9). Participants in a supply chain become strategic partners and links between themchange from simple trans actions to sophisticated collaborative relationships (Wallner et al., 2015). The task of the supply chain manager is to assess the impact of businessdecisions on the entire supply chain, and not only on its specific participants (Ilić \& Tešić, 2016).

With none or poor SCM, participants in the supply chain act as closed, independent entities, with very little or no direct exchange of information, and typically hold large inventories to defend against volatility in demand (Đurić et al., 2012). Such a situation leads to increased costs and reduced agility of businesses, which is a very unfavorable position in the modern market, where rapid and major changes occur frequently. Therefore, the focus has to be moved from the strategy "make and sell" to the more responsive one "feel and react". In other words, instead of the "push" approach based on demand forecast, modernly designed supply chains adopt the "pull" approach based on current customer requirements. Several factors have contributed to the significance of SCM, such as the pres sure of customers on companies to tailor goods to their individual requirements; intensive competition, shorter product life cycle; reduced time of product access to the market; new technologies and request for improvement of services and customer support.

Strategic importance of SCM results from the fact that individual companies can no longer compete on their own, but rather through collaboration with supply chain partne rs. According to Schlegel (1999), SCM should bring numerous benefits, such as improved customer service and value added, better asset utilisation, and increased sales and profitability. There are two basic strategies for gaining competitive advantage, namely, lowcost strategy and differentiation strategy. The first one leads to lower prices to attract pricesensitive customers. The second one is oriented towards customization to offer unique and high quality goods to demanding customers. The SCM enables companies to gain advantage from both strategies simultaneously and avoid traditional trade-offs. Consequently, SCM enables its members to shorten the lead-time, increase product/service availability, decrease costs, as well as to improve quality and customization. The Supply-Chain Council (SCC) has provided the SCOR (supply-chain operations-reference) model, which covers key supply chain activities fromcustomer demand identification to product delivery and cash collection. The goal of the SCOR model is to provide a standardized way to measure supply chain performance and to use common metrics for comparis on with other organizations (benchmarking) (Christopher, 2016, p. 239).

Tellioglu (2021) points out that costs and quality of service are of paramount importance in the contemporary hotel business, while the supply chain has a deep impact on both of these drivers of competitiveness. E-word-of-mouth has made customer satisfaction the primary objective of the hotel business due to its visibility to potential guests worldwide, where any negative comment may have serious consequences for the future hotel operations. To produce quality service and keep guests satisfied, hotels should carefully choose supply chain partners and conduct an effective SCM, which involves the selection of key suppliers and distributors, open communication and collaboration, forecast and planning, inventory management, ICT-based integration, and definition of supply chain performance measures. All supply chain members should have access to real-time information, and their integration should result in learning and improvement of business processes. According to González- 
Torres et al. (2021), the cooperation among participants in the tourism supply chain is a driving force of agility, flexibility and organizational performance. They argue that trans parent and timely communication about difficulties some members of the supply chain face helps other members to anticipate realistic timelines and adjust their operations. Lopes de Sous a Jabbour et al. (2020) state that knowledge management is important for a resilient supply chain, including data collection through group discussion and brainstorming to identify challenges as well as opportunities.

Touris m supply chain (TSC) involves accommodation providers, producers, dis tributors and suppliers of food and other products used for accommodation services, transportation companies, travelagents and touroperators, restaurants, as well as touristic sites, shopping centers and other (Abdelsalam \& Elbelehy, 2020). Each tourism chain is specific as it involves participants and attractions within a certain location. TSC management can be referred to as "a set of approaches utilized to efficiently manage the operations of the tourism supply chain (TSC) within a specific tourism destination to meet the needs of touris ts from the targeted source market(s) and accomplish the business objectives of different enterpris es within the TSC" (Zhang et al., 2009, p. 345). Tour operators have a significant role in TSC, as they connect supply and demand by combining products and services from different suppliers into a single package, which is being allocated to the touris ts or touris magencies (Tigu \& Calaretu, 2013). Thus, tour operators have a strong impact on other participants in the TSC, both upstream and downstream. TSC has certain peculiarities, such as that its members are affected by discontinuity in demand because of seasonality, but also by sys temic changes in tourists preferences which are commonly directed by tour operators. TSC is very sensitive to different types of crises, such as economic, political, health crises or natural dis asters. Moreover, tourism services are consumed directly and personally by guests who need to be physically present at the place where the service is provided; tourism services are perishable in nature, meaning that they cannotbe stored for later use; tourism products cannotbe evaluated before purchase so information availability is necessary; and, there is high demand uncertainty (Zhang et al., 2009). Because touris m offer normally cons is ts of different products and services, efficient coordination among suppliers of those products and services is of high importance.

From the hotel perspective, SCM involves identification of guests' preferences, service design, demand forecast and planning, selection of suppliers and dis tributors and the mode of communication with them, inventory management, and evaluation of guests' satisfaction. The importance of availability of real-time information throughout the supply chain enables faster response and decreases the need for high inventories. This is enabled by software solutions which integrate partners in the supply chain and allow themto access relevant data in order to make proper and timely decisions. Moreover, some ICT tools help hotels with SCM activities, such as market research, demand forecast, service design, customer relations hip management(CRM), event planning, decision-making, inventory management, and others.

\subsection{Dis ruptions in supply chains and hotel business due to COVID-19}

The vulnerability of supply chains results from their complexity and interdependence of their elements, so the problems occurring in one part of the supply chain are felt throughout the whole supply chain with the "ripple" effect. Due to the inherent characteristics of high pers onal contact, hospitality has become one of the hardest-hit industries by the COVID-19 pandemic. Tasnim(2020) as serts that COVID-19 "has an important effect on global supply chain management process" (p. 73). Border closures, travel restrictions, mandatory quarantine, infection, and fear of disease have significantly affected global supply chains, 
both fromthe demand- and supply-side. In some cases, there were bottlenecks along the whole supply chain: "The COVID-19 pandemic has placed unprecedented stresses on food supply chains, with bottlenecks in farm labour, processing, transport and logis tics, as well as momentous shifts in demand." (OECD, 2020). Global supply chains were also seriously disrupted because Chinese suppliers of raw materials, semi-finished and finished products are significant participants in most supply chains (Tellioglu, 2021). Gentile (2020) refers to the Ins titute for Supply Management's survey, which shows that almost half of res pondents did not have a plan regarding supply chain disruption from China. The author further as serts that the situation was the most dramatic in the case of personal protective equipment, as over half of total global supplies comes from China. Welch (2021) claims that the current pandemic has shown how fragile the global supply chain is, and indicates significance of trusted supplier relationship to ensure favorable lead times and quality. Further, the pandemic has contributed to supply chain diversification and reorientation to local suppliers to ensure continuous flows of products and services (BDO, 2021).

The causes of turbulences in the TSC are the lack of products (such as imported food, masks, gloves, disinfectants, inventory, s pare parts for machines, etc.) due to manufacturing closure or limited activity, as well as becau se of surge in demand, lack of trans portation, mandatory closure, lack of knowledge on how to deal with the new situation, employee absenteeism (due to infection, fear, transportation problems, taking care of s mall children and the like), lack of digitalization, or change in consumers buying patterns (Tasnim, 2020). The changes on the supply-side caused prices of commodities and certain services, such as transportation, to increase significantly. On the other hand, as hospitality facilities were closed, there was overstock of certain products, such as meat, causing decline in prices; some products became critical due to legal obligations, and there was als o increased demand for dis posable products to protect human health while waste management has been given secondary importance (Tellioglu, 2021). González-Torres et al. (2021) as sert that TSC members are interlinked in complex patterns, and therefore shed light on the effective upstream and downstream relationship management within the supply chain in order to mitigate the effects of the cris is and achieve sustainable competitiveness. They advocate the shift from transactional relationship to integration and coordination, emphasizing the importance of trust and winwin philosophy among the supply chain members.

The COVID-19 crises has shed light on the importance of considering supply chain dis ruptions in contemporary SCM (Ferreira et al., 2021). Clark (2020) states that disruptions in hos pitality supply chains due to COVID-19 are the consequence of poor visibility and poor supplier relationship management. In order to resist crises, supply chains have to become resilient, which can be achieved through supply chain engineering, a high level of collaboration between the members, agility and risk management culture (Christopher \& Peck, 2004). Through supply chain engineering there should be identified all participants in the supply chain, direct as well as indirect associates, critical path analysis should be performed, and procurement strategy defined (Lopes de Sousa Jabbour et al., 2020). An effective SCM implies collaborative forecasting and planning, as well as sharing real-time information in order to enable timely response to changes and maintenance of small inventories.

Although many hotel facilities were closed, employees at the management and back-office levelcontinued to work, mainly online, performing activities such as maintaining contact with cus tomers and employees, managing reservations, planning future events and the like (Chadee et al., 2021). The use of digital technologies for working from home is being promoted to maintain a certain minimum level of customer service and a relationship with stakeholders. The pandemic has also affected guests' decision-making process and attitude towards using ICTs. Although guests traditionally preferred personal contact over robotic 
staff, the pandemic has changed this attitude as guests became concerned about their health (Kim et al., 2021). Hotels worldwide applied strategies to cope with the COVID-19 pandemic and provide safe service to guests. These were improving hygiene standards and implementing solutions for social distancing using ICTs to reduce guest interaction with hotelemployees, such as check-in machines, and robotic cleaning and serving guests. Apart from effects on the demand side of hotel operations, the pandemic has also influenced the supply side, including hotelemployees, and delivery of goods and services. It was necessary to reassure guests, but also to enable employees to work and ensure their health. The pandemic has occurred to be a new and challenging situation in which service provision, marketing communication, human resource management, and social responsibility need special attention and adjustment. Vasić (2020) finds that many companies in South-East Europe were not prepared for remote working, what caused a lot of stress and anxiety. Summarizing the findings of early empirical research on COVID-19 impact on the hotel industry, Milovanović (2021) points out that hotel recovery strategies include "increasing safety provision through strict hy giene standards, employee trainings and motivation, social distancing, more intensive use of digital technology instead of human contact, intensive marketing to promote safety, safety certification, orientation towards domestic tourists, more attractive offers, medical as sistance, charity giving and room/food provision for those in need especially for displaced medical staff and quarantined tourists, business model innovation, and so on" (p. 582).

To inves tigate the impact of COVID-19 on hotels' SCM in Serbia, the following hypotheses are developed:

$\mathrm{H}_{1.1}$ : Hotels in the Republic of Serbia face difficulties in SCM due to the COVID-19 pandemic.

$\mathrm{H}_{1.2}$ : Higher categ ory hotels face more difficulties in SCM due to the COVID-19 pandemic than lower category hotels.

$\mathrm{H}_{1.3}$ : Large hotels face more difficulties in SCM due to the COVID-19 pandemic than smalland medium-sized hotels .

$\mathrm{H}_{1.4}$ : Hotels belonging to a chain face more difficulties in SCM due to the COVID-19 pandemic than independent hotels.

It is expected that the study results reveal that hotels in the Republic of Serbia have experienced difficulties in SCM due to the COVID-19 pandemic, and that the intensity of difficulties is positively related to hotels' size and category. Such expectation results from the perceived higher complexity of supply chains of hotels of bigger size and higher category. It is als o as sumed that hotels belonging to a hotel chain will face more difficulties than independent hotels, ag ain, because of the perceived higher complexity of supply chains in case of affiliated hotels.

\subsection{Application of ICT tools in the tourism and hos pitality SCM}

ICTs enable supply chains to be highly responsive to market changes by providing efficient solutions for forecasting, planning, purchase, production, transport, storage, distribution and sales. Thanks to the Internet and other ICTs, the concept of SCM has been redefined. The Internet has changed the way people buy goods and gather information about them, while many processes became automated, what has led to the dramatic increase in speed and accuracy (Min, 2015, p. 442). A very important impact of ICTs is reflected in a higher degree of integration between participants in the supply chain, and in significant reduction of adminis trative and procurement costs (Mitrović \& Mitrović, 2019). ICT should not be seen 
only as a tool, because tools can bring some advantages for business, but not development (Soldat \& Matotek, 2014). Data does not imply knowledge, but it is important how the data is found, created and used. The development of ICTs should improve forecasting efficiency and competitiveness through availability and exchange of information between supply chain members. Numerous ICT-based tools are used in SCM, such as Enterprise Resource Planning (ERP), Geographic Information System (GIS), Radio Frequency Identification (RFID), Internet of Things (IoT), Cloud Computing, Big Data, Blockchain, as well as Artificial Intelligence (AI). These tools are going to be discussed in more details.

ERP offers an integrated information control system, connecting different functions within the enterprise, but also between the supply chain participants. It enables members of the supply chain to share the same information in real-time, so business processes can be better coordinated and risk reduced. The ERP sys tem makes it eas ier to do business while reducing bureaucracy and increasing productivity (Beheshti, 2006). Chauhan and Singh (2017) find that ERP is highly relevant for the tourism industry as it helps to enhance service performances, including productivity and operational efficiency. Min (2015, p. 444) lis ts the major benefits of ERP, such as lead-time reduction, faster information trans action, speedy payment, and laying the groundwork for electronic commerce. GIS is a computer system that stores different kinds of spatial information. For SCM, it can be a valuable platform for communication between supply chain members; it can enhance logis tic efficiency, and warn of natural disasters. Yang et al. (2015, p. 16) highlight the main areas of GIS usage in hospitality and tourism management, such as "the research of tourism resource inventories/usage, location suitability, tourism impact analysis and visitor flow management". RFID technology is used for products' electronic identification, reducing labor costs while increasing efficiency and inventory accuracy, making product delivery faster, and eliminating the need for phy sical product inventory (Soldat \& Matotek, 2014). It enables reading product information from greater distances and without direct physical contact, thus enabling data reading in harsh environ ments or chaotic circumstances (Min, 2015, p. 451). Hozak (2012) shows examples of RFID technology application in the touris $m$ industry; namely, it can be used for inventory control and order planning, as well as for tracking of things, such as luggage, uniforms, towels, etc. The author points out that the same RFID card may be used for several purposes.

There are several emerging trends in ICT application to SCM, such as "open collaboration through "cloud computing," "conversation economy" via online social networking media, mobile commerce in ubiquitous environments, and multitasking using smart objects" (Min, 2015, p. 458). The concept of cloud computing refers to sharing res ources over a network, most often the Internet, at any time and independently of a geographic location (Đordjević et al., 2018). Users can access applications on demand via a web browser or desktop/mobile application, while the infras tructure and software are hosted at a remote location. The key benefits include greater accessibility to ICT tools, higher innovative potential, lower costs and improved quality (Marston et al., 2011). Application of cloud computing in the tourism industry includes collection of tourist information on one platform (W ang, 2015). Na et al. (2016) propose a hotel information platform, which integrates tourism and leisure information of a des tination using cloud computing technology. Social media or the so called "conversation economy" enable fast interactive communication involving employees, customers and business partners. It is a good ground for customer relationship management (CRM), advertising, and quick exchange of information.

IoT refers to the interconnection of physical objects, which are seamlessly integrated into the information network and are active participants in business processes. Such objects have built-in electronics, software, sensors, and connectivity that enable them to exchange data with the manufacturer, operator and/or other connected devices (Weber \& Weber, 2010, p. 
1). Abdel-Bassetet al. (2018) as sert that the main benefits of IoT for SCM are increased realtime inventory visibility and logistics transparency to all supply chain members, increased efficiency, lower costs and higher customer satisfaction. IoT is becoming increasingly important in smart tourismdestinations and smart organizations, while examples of IoT in hotels include application-driven devices, automated door locks, thermostats, voice-based interaction, integration with a guest's mobile phone to enable self-check, self check-out and other services, location-based information to advertise hotel services when guests are nearby, offering services such as virtual tour guide, translation services, interactive restaurant menu, sensors enabling maintenance and stock management (Car et al., 2019).

The concept of Big data refers to the design and implementation of a reliable and distributed infrastructure for the storage, analy sis, management, and trans mis sion of large amounts of data (Radenković et al., 2015) which can be accessed by supply chain members in order to enable timely and accurate decision-making. Stylos et al. (2021) state that big data helps organizations in dynamic industries, such as tourism, to predict customer behavior and customize the offer, and they mention photo sharing and review websites as sources of big data in tourism. Blockchain is a database that is not located in one place, but consists of smaller databases (blocks) that are digitally interconnected (Swan, 2015, p. 1). Tasnim (2020) suggests the implementation of digitalization in the platform of blockchain technology in order to create a robust global SCM, which will be able to resist similar future crises. In the hotel business blockchain technology is used for making trans actions, such as bookings or payments, for guests' identification and interaction with them (Ras hideh, 2020). Treiblmaier (2020) summarizes the blockchain use cases in tourism, which involve inventory management, maintenance and tracking, reservations, payment, loyalty programs and pers onalized marketing, s mart contract, privacy as surance, baggage tracking, coordination and cooperation.

The role of $\mathrm{AI}$ is of paramount importance in a modern business due to its ability to collect and analyze data, recognize business patterns, and learn business phenomena (Min, 2010). Ivanov and Webster (2017) show some examples of AI application in the travel, touris $m$ and hospitality industry, such as "chatbots, delivery robots, robot-concierge, conveyor restaurants, self-service information/check-in/check-out kiosks, and many others". The benefits from AI employment in SCM include more efficient decision-making process leading to reduced costs, increased revenue, improved as set utilization, more accurate demand forecast, better quality, more efficient designs for was te removal, real-time tracking and error-free production, and shorter process cycle times (Dash et al., 2019).

Empirical research on the impact of COVID-19 on the implementation of ICTs for SCM is very scarce, particularly in Serbia. To fill this research gap, the following hypotheses are developed:

$\mathrm{H}_{2.1}$ : Hotels in the Republic of Serbia face difficulties in the implementation of ICTs for SCM due to the COVID-19 pandemic.

$\mathrm{H}_{2.2}$ : Higher category hotels face more difficulties in the implementation of ICTs for SCM due to the COVID-19 pandemic than lower category hotels.

$\mathrm{H}_{2.3}$ : Large hotels face more difficulties in the implementation of ICTs for SCM due to the COVID-19 pandemic than small- and medium-sized hotels.

$\mathrm{H}_{2.4}$ : Hotels belonging to a chain face more difficulties in the implementation of ICTs for SCM due to the COVID-19 pandemic than independent hotels.

The study results are expected to provide evidence on the negative effect of COVID-19 on introduction of ICTs for SCM, with the intensity of such effect dependent upon hotels' size, 
category, and affiliation. This expectation is based on the as sumption that hotels of higher category, bigger size, and those affiliated to a hotel chain, use technolog ies for SCM more intensively compared to lower-category, smaller-size and independent hotels, and are therefore more susceptible to negative effects of the pandemic in this regard.

\section{Mate rials and methods}

Empirical research was carried out in May, 2021. The sample consisted of 40 hotel companies of different sizes and affiliations in the Republic of Serbia, which were categorised as 4- and 5-star. One manager per hotel was surveyed. The reason for the selection of hotels with thesetwo categories lies behind the assumption that lower-categ ory hotels may not be using technologies for SCM. The sample characteristics are presented in Table 1.

Table 1: Sample characteristics

\begin{tabular}{|c|c|c|c|c|c|c|c|c|}
\hline & \multicolumn{2}{|c|}{ Hotel category } & \multicolumn{3}{|c|}{ Hotel size } & \multicolumn{2}{c|}{ Chain affiliation } & \multirow{2}{*}{ Total } \\
\cline { 2 - 9 } & 4 -star & 5-star & Small & Medium & Large & Yes & No & \\
\hline Number & 32 & 8 & 18 & 18 & 4 & 7 & 33 & 40 \\
\hline Percent & 80 & 20 & 45 & 45 & 10 & 18 & 82 & 100 \\
\hline
\end{tabular}

Source: Author's research

The respondents were as ked to indicate which ICT-based tools for SCM they use, then, to evaluate to what extent they have faced difficulties in SCM due to the COVID-19 pandemic (1-we have not faced any difficulties; 2 -we have faced small difficulties; 3 -we have faced moderate difficulties; 4-we have faced significant difficulties) and to what extent the COVID-19 pandemic decelerated the implementation of ICTs for SCM (1-no impact; 2 -it decelerated to a s mall extent; 3 -it decelerated to a moderate extent; 4-it decelerated to a great extent). The respondents were also asked if a hotel is independent or it belongs to a hotel chain, what is the size of a hotel (small, medium or large), and what is its categorisation. The statisticalanalysis involved descriptive statistics, t-test and ANOVA, and it was conducted using Statis tical Package for Social Sciences (SPSS) v23.

\section{Results and discussion}

The results of the study reveal that most hotels in the Republic of Serbia categorised as 4and 5-star faced difficulties in SCM due to the COVID-19 pandemic (92\%), as well as regarding implementation of ICTs for SCM $(85 \%)$. The extent of difficulties that each hotel faced varied froms mall to significant, while the majority of respondents assert that they have faced moderate difficulties (Table 2). Based on the obtained results, hypotheses $\mathrm{H}_{1.1}$ and $\mathrm{H}_{2.1}$ are accepted. 
Table 2: Impact of COVID-19 on hotels' SCM and implementation of ICTs for SCM

\begin{tabular}{|l|c|c|c|c|c|c|}
\hline \multicolumn{1}{|c|}{ Variable } & None & Small & Moderate & Significant & Mean & $\begin{array}{c}\text { Standard } \\
\text { deviation }\end{array}$ \\
\hline $\begin{array}{l}\text { Difficulties in } \\
\text { SCM due to } \\
\text { COVID-19 }\end{array}$ & $8 \%$ & $12 \%$ & $50 \%$ & $30 \%$ & 3.03 & 0.86 \\
\hline $\begin{array}{l}\text { Difficulties in } \\
\text { the } \\
\text { implementation } \\
\text { of ICTs for } \\
\text { SCM due to } \\
\text { COVID-19 }\end{array}$ & $15 \%$ & $10 \%$ & $40 \%$ & $35 \%$ & 2.95 & 1.04 \\
\hline
\end{tabular}

Source: Author's research

The T-test was us ed to investigate whether there are any significant differences between 4and 5-starhotels in terms of difficulties that hotels have faced in SCM and introduction of ICTs for SCM due to the COVID-19 pandemic. Since there are two versions of the t-test depending on whether the variances of the two groups (4-and 5-star hotels) are assumed to be equal, Levene's test for equality of variances was performed. The results of Levene's test are not statistically significant, indicating that the t-test with equal variances assumed needs to be used (Table 3).

Table 3: Test for equality of variances of the two groups: 4- and 5-star hotels

\begin{tabular}{|l|c|c|}
\hline \multirow{2}{*}{ Variable } & \multicolumn{2}{|c|}{ Levene's tes t for equality of variances } \\
\cline { 2 - 3 } & $\mathrm{F}$ & $\mathrm{p}$-value \\
\hline Difficulties in SCM due to COVID-19 & 2.949 & 0.094 \\
\hline $\begin{array}{l}\text { Difficulties in the implementation of ICTs for } \\
\text { SCM due to COVID-19 }\end{array}$ & 2.218 & 0.145 \\
\hline
\end{tabular}

$* \mathrm{p} \leq 0.05$

Source: Author's research

The results of the t-test show that there is no statistically significant difference in means between 4-and 5-star hotels regarding difficulties that hotels have faced in SCM and the introduction of ICTs for SCM due to the COVID-19 pandemic (Table 4). This means that on average, the pandemic has equally affected 4 - and 5-star hotels in this respect. Therefore, hypotheses $\mathrm{H}_{1.2}$ and $\mathrm{H}_{2.2}$ could not be accepted.

Table 4: Impact of COVID-19 on hotels' SCM and the implementation of ICTs for SCM according to category

\begin{tabular}{|c|c|c|c|c|c|c|}
\hline \multirow{3}{*}{ Variable } & \multicolumn{6}{|c|}{ Hotel category } \\
\hline & \multicolumn{2}{|c|}{ 4-star } & \multicolumn{2}{|c|}{5 -star } & \multirow{2}{*}{$\mathrm{t}$} & \multirow{2}{*}{ p-value } \\
\hline & M & SD & M & SD & & \\
\hline Difficulties in SCM due to COVID-19 & 3.03 & 0.93 & 3.00 & 0.53 & 0.091 & 0.928 \\
\hline $\begin{array}{l}\text { Difficulties in the implementation of } \\
\text { ICTs for SCM due to COVID- } 19\end{array}$ & 2.97 & 1.09 & 2.88 & 0.83 & 0.226 & 0.822 \\
\hline \multicolumn{6}{|c|}{$\mathrm{M}-$ arithmetic mean; SD - standard deviation; $\mathrm{t}$-test; ${ }^{*} \mathrm{p} \leq 0.05$} & \\
\hline
\end{tabular}

Source: Author's research 
Large hotels face on average the most difficulties in SCM due to COVID-19, followed by small hotels, while the situation was the least unfavorable in medium-sized hotels. In terms of introducing ICTs for SCM, the severity of difficulties decreased with the increase in the size of hotels. In order to test whether these differences among small, medium and large hotels are significant, one way ANOVA was used. Since the assumption of equality of variance needs to be met for one way ANOVA to be used, Levene's test for equality of variances was performed. The results of Levene's test are not statistically significant, indicating that the as sumption of equality of variances of the three groups (s mall, medium and large hotels) is met (Table 5).

Table 5: Test for equality of variances of the three groups: small, medium and large hotels

\begin{tabular}{|l|c|c|}
\hline \multirow{2}{*}{ Variable } & \multicolumn{2}{|c|}{ Levene's test for equality of variances } \\
\cline { 2 - 3 } & $\mathrm{F}$ & $\mathrm{p}$-value \\
\hline Difficulties in SCM due to COVID-19 & 2.466 & 0.099 \\
\hline $\begin{array}{l}\text { Difficulties in the implementation of } \\
\text { ICTs for SCM due to COVID-19 }\end{array}$ & 2.407 & 0.104 \\
\hline
\end{tabular}

$* \mathrm{p} \leq 0.05$

Source: Author's research

The results of the one way ANOVA point out that the differences in means among small, medium and large hotels are not statis tically significant (Table 6), and therefore hypotheses $\mathrm{H}_{1.3}$ and $\mathrm{H}_{2.3}$ are not confirmed.

Table 6: Impact of COVID-19 on hotels' SCM and implementation of new technologies for SCM according to size

\begin{tabular}{|c|c|c|c|c|c|c|c|c|}
\hline \multirow{3}{*}{ Variable } & \multicolumn{8}{|c|}{ Hotel size } \\
\hline & \multicolumn{2}{|c|}{ Small } & \multicolumn{2}{|c|}{ Medium } & \multicolumn{2}{|c|}{ Large } & \multirow{2}{*}{$\mathrm{F}$} & \multirow{2}{*}{ p-value } \\
\hline & $\mathrm{M}$ & SD & M & SD & $\mathrm{M}$ & SD & & \\
\hline $\begin{array}{l}\text { Difficulties in SCM } \\
\text { due to COVID-19 }\end{array}$ & 3.17 & 1.04 & 2.83 & 0.71 & 3.25 & 0.50 & 0.817 & 0.450 \\
\hline $\begin{array}{l}\text { Difficulties in the } \\
\text { implementation of } \\
\text { ICTs for SCM due to } \\
\text { COVID-19 }\end{array}$ & 3.00 & 1.24 & 2.94 & 0.80 & 2.75 & 1.26 & 0.091 & 0.913 \\
\hline
\end{tabular}

$\mathrm{M}$ - arithmetic mean; SD - standard deviation; F-test in ANOVA analys is; * $\mathrm{p} \leq 0.05$ Source: Author's research

Finally, the t-test was used to investigate whether there are any significant differences between independent hotels and those belonging to hotel chains in terms of difficulties that hotels have faced in SCM and the introduction of ICTs for SCM due to the COVID-19 pandemic. The results of Levene's test are not statistically significant, indicating that the ttest with equal variances as sumed needs to be used (Table 7). 
Table 7: Test for equality of variances of the two groups: independent hotels and those belonging to hotel chains

\begin{tabular}{|l|c|c|}
\hline \multirow{2}{*}{ Variable } & \multicolumn{2}{|c|}{ Levene's test for equality of variances } \\
\cline { 2 - 3 } & $\mathrm{F}$ & p-value \\
\hline Difficulties in SCM due to COVID-19 & 1.620 & 0.211 \\
\hline $\begin{array}{l}\text { Difficulties in the implementation of } \\
\text { ICTs for SCM due to COVID-19 }\end{array}$ & 1.161 & 0.288 \\
\hline
\end{tabular}

$* \mathrm{p} \leq 0.05$

Source: Author's research

The results of the t-testhighlight that there is no statistically significant difference in means between independent hotels and those belonging to hotel chains regarding the level of difficulties hotels have faced in SCM and the implementation of ICTs for SCM due to COVID-19 (Table 8). Consequently, hypotheses $\mathrm{H}_{1.4}$ and $\mathrm{H}_{2.4}$ are not supported.

Table 8: Impact of COVID-19 on hotels' SCM and implementation of ICTs for SCM according to affiliation

\begin{tabular}{|c|c|c|c|c|c|c|}
\hline \multirow{3}{*}{ Variable } & \multicolumn{6}{|c|}{ Chain affiliation } \\
\hline & \multicolumn{2}{|c|}{ Yes } & \multicolumn{2}{|c|}{ No } & \multirow{2}{*}{$\mathrm{t}$} & \multirow{2}{*}{$\begin{array}{c}\mathrm{p}- \\
\text { value }\end{array}$} \\
\hline & $\mathrm{M}$ & SD & $\mathrm{M}$ & SD & & \\
\hline $\begin{array}{l}\text { Difficulties in SCM } \\
\text { due to COVID-19 }\end{array}$ & 3.00 & 1.15 & 3.03 & 0.81 & 0.083 & 0.934 \\
\hline $\begin{array}{l}\text { Difficulties in the } \\
\text { implementation of ICTs } \\
\text { for SCM due to } \\
\text { COVID-19 }\end{array}$ & 2.86 & 1.21 & 2.97 & 1.02 & 0.258 & 0.798 \\
\hline
\end{tabular}

$\mathrm{M}$ - arithmetic mean; $\mathrm{SD}$ - standard deviation; $\mathrm{t}$-test; ${ }^{*} \mathrm{p} \leq 0.05$

Source: Author's research

\section{Conclusion}

The COVID-19 pandemic has altered the whole world, causing many disruptions and changes. It has demonstrated how fragile modern supply chains are due to high complexity, and how important an effective supply chain management (SCM) is. The role of SCM is to ensure competitive advantage for the supply chain members through close collaboration, which includes trust, open communication and real-time data sharing, joint planning, and managing supplier relationships. SCM depends on ICTs to a large extent and numerous ICT tools have been developed for the needs of SCM, such as Enterprise Resource Planning (ERP), Geographic Information System (GIS), Radio Frequency Identification (RFID), Internet of Things (IoT), Cloud Computing, Big Data, Blockchain, and Artificial Intelligence (AI). Effective SCM results in increased supply chain agility, lower costs, better quality and customer service, and, consequently, in customer satisfaction, competitive advantage and profitability.

The present study deals with the impact of the COVID-19 pandemic on SCM, focusing primarily on the hotel business. The aim of empirical research was to investigate whether hotels in the Republic of Serbia have experienced difficulties in SCM due to the COVID-19 pandemic, and how serious those difficulties are. The results show that the pandemic has caused dis ruptions in hotels' SCM, with the significance of dis ruptions varying among 
hotels. It was also found that the pandemic has decelerated the implementation of ICTs for the SCM. Contrary to expectations, the results reveal that severity of difficulties in hotels' SCM and the introduction of ICTs for SCM due to COVID-19 does not depend on hotel size, category or affiliation.

The main limitation of the study is reflected in the aggregate presentation of the impact of COVID-19 on hotels 'SCM and on the introduction of ICTs for SCM. As it was identified that hotels faced difficulties in SCM due to COVID-19, future research should investigate that impact in more detail, i.e. what was the weakest point of the supply chain during the pandemic, what kind of difficulties hotels faced, and what strategies hotels employed to overcome those difficulties.

\section{Acknowledgement}

This work was supported by the Ministry of Education, Science and Technological Development of the Republic of Serbia.

\section{Conflict of interest}

The authors declare no conflict of interest.

\section{References}

1. Abdel-Basset, M., Manogaran, G., \& Mohamed, M. (2018). Internet of Things (IoT) and its impact on supply chain: A framework for building smart, secure and efficient systems. Future Generation Computer Systems, 86, 614-628. https://doi.org/10.1016/j.future.2018.04.051

2. Abdelsalam, A., \& Elbelehy, C. (2020). The early impact of COVID-19 on tourism industry: Assessment of Egyptian touris msupply chain. 10th International Conference on Operations and Supply Chain Management (pp. 1-12). Victoria University of Wellington \& Institut Teknologi Sepuluh Nopember (ITS), Indonesia.

3. Ayers, J. B. (2006). Handbook of supply chain management. Florida, Boca Raton: CRC Press.

4. BDO Canada. (2021). Procurement and supply chain strategies for COVID-19 disruptions. Retrieved October 14, 2021 from https://www.bdo.ca/en$\mathrm{ca} /$ insights/advisory/procurement/procurement-and-supply-chain-strategies-duringcovid-19/

5. Beheshti, H. M. (2006). What managers should know about ERP/ERP II. Management Research News, 29(4),184-193. https://doi.org/10.1108/01409170610665040

6. Car, T., Pilepić Stifanich, Lj., \& Šimunić, M. (2019). Internet of things (IOT) in tourism and hos pitality: Opportunities and challenges. Tourism in Southern and Eastern Europe (ToSEE), 5, 163-175. https://doi.org/10.20867/tosee.05.42

7. Chadee, D., Ren, S., \& Tang, G. (2021). Is digital technology the magic bullet for performing work at home? Lessons learned for post COVID-19 recovery in hos pitality management. International Journal of Hospitality Management, 92, 1-8. https://doi.org/10.1016/j.ijhm.2020.102718

8. Chauhan, V., \& Singh, J. (2017). Enterprise resource planning systems for service performance in tourismand hospitality industry. International Journal of Hospitality \& Tourism Systems, 10(1), 57-62.

9. Christopher, M. (2016). Logistics \& supply chain management (5th ed.). UK, London: Pearson. 
10. Christopher, M., \& Peck, H. (2004). Building the resilient supply chain. International Journal of Logistics Management, 15, 1-14. https://doi.org/10.1108/09574090410700275

11. Clark, J. (2020). The impact of COVID-19 on your hospitality supply chain. Retrieved October 14, 2021 from https://www.ukhospitality.org.uk/blogpost/1721400/357732/TheImpact-of-COVID-19-on-your-Hospitality-Supply-Chain

12. Dash, R., McMurtrey, M., Rebman, C., \& Kar, U. K. (2019). Application of artificial intelligence in automation of supply chain management. Journal of Strategic Innovation and Sustainability, 14(3), 43-53.

13. Đordjević, M., Radović, O., \& Bonić, L. (2018). Potentials for applying cloud technology in accounting. Ekonomika, 64(3), 23-30. http://dx.doi.org/10.5937/ekonomika1803023D

14. Đurić, M., Vujošević, M, \& Kovačević, N. (2012). The impacts of organizations's social responsibility on the supply chain management. In M. Levi Jakšić \& S. Barjaktarović Rakočević (Eds.), Innovative Management \& Business Performance (pp. 476-484). Belgrade: University of Belgrade, Faculty of Organis ational Sciences.

15. Ferreira, C., Cardoso, C., Travassos, M., Paiva, M., Pestana, M., Lopes, J. M., \& Oliveira, M. (2021). Disorders, vulnerabilities and resilience in the supply chain in pandemic times. Logistics, 5(3), 48. https://doi.org/10.3390/logis tics5030048

16. Gentile, F. (2020). Re-thinking supply chain risks in the face of COVID-19. Retrieved October 14, 2021 from https://www.willistowers watson.com/enGB/Insights/2020/05/re-thinking-supply-chain-risks-in-the-face-of-covid-19

17. González-Torres, T., Rodríguéz-Sánchez, J. L., \& Pelechano-Barahona, E. (2021). Managing relationships in the Tourism Supply Chain to overcome epidemic outbreaks: The case of COVID-19 and the hospitality industry in Spain. International Journal of Hospitality Management, 92. https://doi.org/10.1016/j.ijhm.2020.102733

18. Grant, B. D., Trautrims, A., \& Wong, Y. C. (2017). Sustainable logistics and supply chain management. Principles and practices for sustainable operations and management (2nd ed.). New York: Kogan Page Ltd.

19. Hozak, K. (2012). Managerial guidance for applying RFID in the tourism industry. Interdisciplinary Journal of Contemporary Research in Business, 14(2), 18-30.

20. Ilić, D., \& Tešić, A. (2016). The relationship between supply chain management strategy, marketing, logistics and company performance for breweries in Serbia. Economics of A griculture, 63(4), 1157-1168. https://doi.org/10.5937/ekoPolj1604157I

21. Ivanov, S., \& Webster, C. (2017). Adoption of robots, artificial intelligence and service automation by travel, tourism and hospitality companies - a cost-benefit analysis. Contemporary Tourism - Traditions and Innovations. Sofia University, Bulgaria.

22. Kim, S. S., Kim, J., Badu-Baiden, F., Giroux, M., \& Choi, Y. (2021). Preference for robot service or human service in hotels? Impacts of the COVID-19 pandemic. International Journal of Hospitality Management, 93, 1-12. https://doi.org/10.1016/j.ijhm.2020.102795

23. Lopes de Sousa Jabbour, A. B., Chiappetta Jabbour, C. J., Hingley, M., VilaltaPerdomo, E. L., Ramsden, G., \& Twigg, D. (2020). Sustainability of supply chains in the wake of the coronavirus (COVID-19/SARS-CoV-2) pandemic: Lessons and trends. Modern Supply Chain Research and Applications, 2(3), 117-122. https://doi.org/10.1108/MSCRA-05-2020-0011

24. Luque-Martínez, T., Castañeda-García, J. A., Frías-Jamilena, D. M., Muñoz-Leiva, F., \& Rodríguez-Molina, M. A. (2007). Determinants of the use of the Internet as a tourist information source. The Service Industries Journal, 27(7), 881-891. https ://doi.org/10.1080/02642060701570586 
25. Marston, S., Li, Z., Bandyopadhyay, S., Zhang, J., Ghalsasi, A. (2011). Cloud computing - The business perspective. Decision Support Systems, 51(1), 176-189. https://doi.org/10.1016/j.dss.2010.12.006

26. Milovanović, V. (2021). The COVID-19 pandemic effects on the hotel industry. In D. Cvijanović et al. (Eds.), Tourism challenges amid COVID-19 (pp. 570-587). Vrnjačka Banja, Serbia: University of Kragujevac - Faculty of Hotel Management and Touris $m$ in Vrnjačka Banja. https://doi.org/10.52370/TISC21570VM

27. Min, H. (2010). Artificial intelligence in supply chain management: Theory and applications. International Journal of Logistics: Research and Applications, 13(1), 1339. https://doi.org/10.1080/13675560902736537

28. Min, H. (2015). The essentials of supply chain management - New business concepts and applications. USA: Pears on Education LTD.

29. Mitrović, V., \& Mitrović, I. (2019). Savremeni koncepti upravljanja lancima snabdevanja upotrebom informaciono-komunikacionih tehnologija [Contemporary concept of management of lans of supply with information and communication technology]. Ekonomski signali, 14(2), 81-96. https://doi.org/10.5937/ekonsig1902081X

30. Na, L., Xueyuan, W., \& Yulian, X. (2016). Hotel information platform design and implementation based on cloud computing. International Joumal of Hybrid Information Technology, 9(3), 61-72. http://dx.doi.org/10.14257/ijhit.2016.9.3.06

31. OECD. (2020). Food supply chains and COVID-19: Impacts and policy lessons. Retrieved October 14, 2021 from https://www.oecd.org/coronavirus/policyres ponses/food-supply-chains-and-covid-19-impacts-and-policy-les sons-71b57aea/

32. Radenković, B., Des potović-Zrakić, M., Bogdanović, Z., Barać, D., \& Labus A. (2015). Elektronsko poslovanje [E-Business]. Belgrade: University of Beolgrade - Faculty of Organis ational Sciences.

33. Rashideh, W. (2020). Blockchain technology framework: Current and future perspectives for the tourism industry. Tourism Management, 80(104125). https://doi.org/10.1016/j.tourman.2020.104125

34. Schlegel, G. L. (1999). Supply chain optimization: A practitioner's pers pective. Supply Chain Management Review, 11(4), 50-57.

35. Soldat, S. D., \& Matotek, Đ. M. (2014). Supply chain optimization by implementation of modern ICT. Tehnika, 64(6), 1067-1072. https ://doi.org/10.5937/tehnika1406067S

36. Stylos, N., Zwiegelaar, J., \& Buhalis, D. (2021). Big data empowered agility for dynamic, volatile, and time-sensitive service industries: The case of tourism sector. International Journal of Contemporary Hospitality Management, 33(3), 1015-1036. https://doi.org/10.1108/IJCHM-07-2020-0644

37. Swan, M. (2015). Blockchain: Blueprint for a new economy. California, Sebastopol: O'Reilly Media, Inc.

38. Tasnim, Z. (2020). Disruption in global Food Supply Chain (FSCs) due to Covid-19 pandemic and impact of digitalization through block chain technology in FSCs management. European Journal of Business and Management, 12(17),73-84.

39. Tellioglu, S. (2021). The impact of COVID-19 on supply chains of all-inclusive hotels. GeoJournal of Tourism and Geosites, 35(2), 464-470. https://doi.org/10.30892/gtg.35226-673

40. Tigu, G., \& Calaretu, B. (2013). Supply chain management performance in touris $m$ Continental hotels chain case. Amfiteatru Economic, 15(33), 103-115.

41. Treiblmaier, H. (2020). Blockchain and touris m. In Z. Xiang et al. (Eds.), Handbook of e-Tourism (pp. 1-20). Springer Nature Switzerland AG. https ://doi.org/10.1007/978-3030-05324-6_28-1 
42. Vasić, M. (2020). Challenges of teleworking during the COVID-19 pandemic. The Annals of the Faculty of Economics in Subotica, 56(44), 63-79. https ://doi.org/10.5937/AnEkSub2044063V

43. Wallner, M., Brunner, U., \& Zsifkovits, H. (2015). Modelling complex planning processes in supply shains. In W. Kersten et al. (Eds.), Operational Excellence in Logistics and Supply Chains (pp. 3-30). Hamburg, Germany: Hamburg University of Technology.

44. Wang, N. (2015). Research on construction of smart tourism perception system and management platform. In P. Chen \& S. Zhang (Eds.), International Conference on Education, Management and Computing Technology (pp. 89-92). Tijanjin, China.

45. Weber, R. H., \& Weber, R. (2010). Internet of things, Germany, Berlin: Springer, Heidelberg.

46. Welch, C. (2021). Global supply chain dis ruption: How the COVID-19 pandemic impacted the hospitality industry. Retrieved October 14, 2021 from https://www.elkayinteriors ys tems.com/en/covid-19-res ponse/innovation-throughdesign/global-supply-chain-dis ruption.html

47. Yang, Y., Tang, J., Luo, H., \& Law, R. (2015). Hotel location evaluation: A combination of machine learning tools and web GIS. International Journal of Hospitality Management, 47, 14-24. https ://doi.org/10.1016/j.ijhm.2015.02.008.

48. Zhang, X., Song, H., \& Huang, G. Q. (2009). Tourism supply chain management: A new research agenda. Tourism Management, 30(3), 345-358. https://doi.org/10.1016/j.tourman.2008.12.010 